\title{
IMPLEMENTASI MEDIASI TERHADAP PENYELESAIAN PERKARA WARIS DALAM MEWUJUDKAN KEPASTIAN HUKUM DI PENGADILAN AGAMA
}

\author{
M. Arufin \\ Program Pascasarjana, Universitas Islam Bandung \\ E-mail: hm.arufin@gmail.com
}

\begin{abstract}
Abstrak - Peradilan Agama telah menerapkan mediasi sesuai Perma Nomor 1 Tahun 2016, realitanya terdapat gap antara teori dengan implementasi, terkhusus perkara waris di Pengadilan Agama. Tujuan penelitian ini: 1)Menggali dan mengungkapkan kompetensi skill mediator yang dibutuhkan dalam menyelesaikan mediasi perkara waris di wilayah PTA. Surabaya,2)Mengungkapkan kemaslahatan bagi para pihak yang bersengketa dalam penyelesaian perkara waris melalui implementasi mediasi di wilayah PTA. Surabaya,3)Menyingkap efektivitas mediasi yang dikaitkan dengan teori kepastian hukum dalam penyelesaian sengketa perkara waris di wilayah PTA. Surabaya. Metode menggunakan pendekatan perundang-undangan, kasus, dan konseptual, teknik pengumpulan dengan dokumentasi dan wawancara. Hasil penelitian: 1)Kompetensi skill mediator bersertifikat yang menangani perkara waris belum optimal, 2)Implementasi mediasi perkara waris sudah berjalan sesuai Perma Nomor 1 tahun 2016, namun kemaslahatan belum optimal, 3)Mediasi perkara waris yang efektif dapat mendukung kepastian hukum, tahun 2014-2015, hingga saat ini, kepastian hukum dalam penyelesaian sengketa perkara waris melalui mediasi di Pengadilan Agama wilayah PTA. Surabaya belum efektif.
\end{abstract}

Kata Kunci: Implementasi, Mediasi Perkara waris dan Kepastian Hukum

\begin{abstract}
The Religious Courts have implemented mediation in accordance with Law No. 1 of 2016, in reality there is a gap between theory and implementation, especially inheritance cases in the Religious Courts. The purpose of this study: 1) To explore and reveal the mediator skill competencies needed to complete the mediation of inheritance cases in the PTA area. Surabaya, 2) Expressing benefit for the parties to the dispute in the settlement of inheritance cases through the implementation of mediation in the PTA region. Surabaya, 3) Revealing the effectiveness of mediation that is associated with the theory of legal certainty in resolving disputes in inheritance cases in the PTA region. Surabaya. The method uses a legislative, case and conceptual approach, collection techniques with documentation and interviews. The results of the study: 1) Competence of certified mediator skills that handle inheritance cases has not been optimal, 2) Implementation of inheritance cases has been in line with Perma Number 1 of 2016, but benefit is not optimal, 3) Mediation of effective inheritance cases can support legal certainty, 2014 2015, to date, legal certainty in resolving inheritance cases disputes through mediation in the PTA Religious Court. Surabaya has not been effective.
\end{abstract}

Keywords: Implementation, Mediation of inheritance cases and legal certainty

\section{A. PENDAHULUAN}

Ditemukan fakta bahwa mediasi belum efektif menanggulangi tumpukan perkara waris di wilayah Pengadilan Tinggi Agama Surabaya, temuan awal sementara diketahui profesionalisme 
fungsi mediator yang bersertifikat belum terlihat optimal dan diduga memengaruhi keberhasilan mediasi di Pengadilan Agama wilayah Pengadilan Tinggi Agama Surabaya, di lain sisi keberadaan penerapan mediasi di Pengadilan Agama tidak bertentangan dengan hukum Islam. Berdasarkan temuan data di Pengadilan Agama-Pengadilan Agama di wilayah Pengadilan Tinggi Agama Surabaya, akan dikemukakan dalam tabulasi sebagai berikut:

\section{Tabel 1}

Penyelesaian Kasus Perkara Waris di wilayah Pengadilan Tinggi Agama

\begin{tabular}{|c|c|c|c|c|c|c|c|c|}
\hline \multirow{2}{*}{$\begin{array}{c}\text { Tahu } \\
\mathrm{n}\end{array}$} & \multicolumn{2}{|c|}{$\begin{array}{c}\text { P.A.La } \\
\text { monga }\end{array}$} & \multicolumn{2}{c|}{$\begin{array}{c}\text { P.A.T } \\
\text { uban }\end{array}$} & \multicolumn{2}{c|}{$\begin{array}{c}\text { P.A. } \\
\text { Gresi }\end{array}$} & \multicolumn{2}{|c|}{$\begin{array}{l}\text { P.A.Su } \\
\text { rabaya }\end{array}$} \\
\cline { 2 - 9 } & Ks & $\begin{array}{c}\text { M } \\
\text { K }\end{array}$ & $\begin{array}{c}\text { M } \\
\text { K }\end{array}$ & $\begin{array}{c}\text { M } \\
\text { K }\end{array}$ & $\begin{array}{c}\text { M } \\
\text { d }\end{array}$ \\
\hline 2012 & 1 & - & 7 & - & 4 & - & 23 & - \\
\hline 2013 & 6 & - & 5 & - & 4 & 1 & 35 & - \\
\hline 2014 & 2 & - & - & - & 6 & - & 21 & - \\
\hline $\begin{array}{c}\% \\
\text { keber } \\
\text { hasil } \\
\text { an }\end{array}$ & \multicolumn{2}{|c|}{$0 \%$} & $0 \%$ & $7,1 \%$ & \multicolumn{2}{|c|}{$0 \%$} \\
\hline
\end{tabular}

Sumber: badilag.net 2014 diolah peneliti (2017) Ks : Kasus

Md: diselesaikan dengan Mediasi

Berdasarkan tabel 1 diketahui bahwa kasus perkara waris yang ditangani Pengadilan Agama di wilayah kerja Pengadilan Tinggi Agama Surabaya, dalam hal keberhasilan proses mediasi yang ditempuh sebagai proses penyelesaian perkara dari 4 (empat) Pengadilan Agama sepanjang tahun 2012 sampai tahun 2014, hanya 1 kasus perkara waris di kabupaten Gresik yang diselesaikan melalui jalur mediasi, yang mana untuk 1 (satu) kasus yang ditangani tahun 2013 di Pengadilan Agama Gresik tersebut pada akhirnya dituangkan dalam akta perdamaian oleh putusan Majelis Hakim Pengadilan Agama Kabupaten Gresik.

Kondisi ketidakberhasilan penyelesaian perkara waris melalui jalur mediasi secara umum diketahui disebabkan oleh beberapa hal, di samping faktor internal mediator antara lain kompetensi mediator secara individu, padahal salah satu yang mendukung keberhasilan mediasi adalah kompetensi mediator yang benar-benar konsens, simultan dan profesional melakukan mediasi, sehingga keberadaan mediator bersertifikat yang umumnya berasal dari jalur non hakim belum menunjukkan keberhasilan yang signifikan dalam memediasi perkara waris di wilayah PTA Surabaya.

\section{Peradilan}

agama

telah mempraktikkan mediasi berdasarkan Perma Nomor 1 Tahun 2016, namun demikian, terdapat sejumlah kesenjangan antara teori mediasi dengan implementasinya di pengadilan agama, 
baik berdasarkan pengamatan peneliti pada saat melaksanakan tugas sebagai Hakim PA ataupun berdasarkan kajian empiris yang telah dilakukan oleh peneliti terdahulu yaitu: Hasil evaluasi oleh Mahkamah Agung Republik Indonesia yang dikemukakan dalam Dokumen Reviu Kedua Rencana Strategis Mahkamah Agung Tahun 2015-2019 diketahui dari tahun $2013^{1}$, berdasarkan hasil laporan tahunan, tingkat keberhasilan mediasi belum efektif yaitu berkisar $20 \%$ hal ini disebabkan oleh karena mediasi di lingkungan Peradilan Umum dan Peradilan Agama memang belum menjadi pilihan utama bagi pencari keadilan dalam penyelesaian sengketa/perkara.

Berdasarkan realita ini, dapat disimpulkan bahwa masalah yang akan dikaji dalam penyusunan disertasi ini adalah terdapat kesenjangan yang lebar antara konsep dan cita ideal mediasi dengan fakta mediasi di lapangan. Realitas yang demikian ini mendorong peneliti untuk melakukan penelitian secara mendalam tentang pelaksanaan mediasi perkara waris di Pengadilan Agama in cassu di wilayah Pengadilan Tingi Agama Surabaya, yang di dalamnya meliputi pula faktor-faktor yang menunjang keberhasilan mediasi dan faktor-faktor yang menjadi

\footnotetext{
${ }^{1}$ Dokumen Reviu Rencana Strategis (Renstra) Mahkamah Agung Tahun 2015-2019, Penerbit Mahkamah Agung RI, Jakarta, April 2017

kendala yang mengakibatkan mediasi dan perdamaian perkara waris sulit tercapai, dan selanjutnya perlu dilakukan langkahlangkah kongkrit dan aplikatif secara konsepsional, terukur dan terstruktur sehingga bisa mengoptimalkan mediasi perkara waris di Pengadilan Agama, dan pada akhirnya target yang hendak dicapai mediasi/perdamaian dapat berhasil.

Menurut peneliti, hal penting yang perlu digarisbawahi adalah bahwa keberadaan mediasi dalam menyelesaikan perkara waris harus dilakukan oleh mediator yang cukup memiliki profesionalisme dan kompetensi sesuai dengan perkara yang ditangani, terlebih perkara waris. Kondisi masih banyaknya ketidakberhasilan penyelesaian perkara waris melalui jalur mediasi secara umum, menjadikan indikasi bahwa proses mediasi perkara waris belum efektif, dan dikuatirkan menimbulkan ketidak pastian hukum dalam proses penyelesaiannya di masa yang akan datang.

Keberadaan sengketa perkara waris yang merupakan bagian dari acara perdata dapat diselesaikan melalui jalur mediasi secara formal didukung dengan payung hukum sesuai Perma Nomor 1 tahun 2016 Huruf (d) tentang prosedur Mediasi : bahwa Prosedur Mediasi di Pengadilan menjadi bagian hukum acara perdata dapat memperkuat dan mengoptimalkan fungsi lembaga peradilan dalam penyelesaian 
sengketa ${ }^{2}$; Sehingga dengan demikian maka bidang waris merupakan bidang hukum perdata yang dapat diselesaikan sengketanya dengan perdamaian yang kewenangan sepenuhnya ada pada para pihak.

Berdasarkan uraian tentang latar belakang masalah yang dikemukakan, peneliti mengidentifikasi masalah pokok yang akan dibahas dalam disertasi ini sebagai berikut:

1. Sejauhmana kompetensi skill mediator yang dibutuhkan dalam menangani mediasi sengketa perkara waris di wilayah Pengadilan Tinggi Agama Surabaya?

2. Sejauhmana implementasi mediasi memberi kemaslahatan bagi para pihak yang bersengketa dalam penyelesaian perkara waris di wilayah Pengadilan Tinggi Agama Surabaya?

3. Sejauhmana efektivitas mediasi dikaitkan dengan teori kepastian hukum dalam penyelesaian sengketa perkara waris di wilayah Pengadilan Tinggi Agama Surabaya?

Penelitian ini dilaksanakan dengan tujuan untuk mengkaji dan mengungkap hal-hal sebagai berikut:

1. Menggali dan mengungkapkan kompetensi skill mediator yang dibutuhkan dalam menyelesaikan

${ }^{2}$ Perma Nomor 1 tahun 2016, tentang Prosedur Mediasi mediasi perkara waris di wilayah Pengadilan Tinggi Agama Surabaya.

2. Mengungkapkan kemaslahatan bagi para pihak yang bersengketa dalam penyelesaian perkara waris melalui implementasi mediasi di wilayah Pengadilan Tinggi Agama Surabaya.

3. Menyingkap efektivitas mediasi yang dikaitkan dengan teori kepastian hukum dalam penyelesaian sengketa perkara waris di wilayah Pengadilan Tinggi Agama Surabaya.

\section{Metode}

Tipe penelitian ini adalah penelitian hukum normatif empiris, peneliti meneliti bahan kepustakaan khususnya yang berkaitan dengan mediasi, sebagai pendukung untuk meneliti paraturan mediasi sebagaimana diatur dalam Perma No. 1 Tahun 2016 tentang Prosedur Mediasi di Pengadilan, selain itu peneliti meneliti pelaksanaan mediasi perkara waris yang terjadi dalam praktik di wilayah Pengadilan Tinggi Agama Surabaya dihubungkan dengan Perma No. 1 Tahun 2016 tersebut. Disamping itu, peneliti juga melakukan penelitian yang berorentasi pada perubahan (reform oriented research), yaitu penelitian yang secara intensif mengevaluasi pemenuhan ketentuan yang sedang berlaku dan merekomendasikan perubahan terhadap 
peraturan manapun yang dibutuhkan. ${ }^{3} \mathrm{Hal}$ ini karena dalam penelitian ini setelah peneliti meneliti pelaksanaan mediasi perkara waris secara mendalam sebagai implementasi Perma No. 1 Tahun 2016, peneliti merekomendasikan beberapa hal demi terlaksanakannya mediasi perkara waris secara optimal dengan hasil yang optimal juga.

Data primer penelitian ini diperoleh di lapangan melalui wawancara dengan pihak yang terlibat dalam pelaksanaan mediasi, antara lain Pimpinan Pengadilan, Hakim, Mediator bersertifikat, Advokat dan pencari keadilan pada Pengadilan Tinggi Agama Surabaya serta hasil praktik mediasi perkara waris di Pengadilan Tinggi Agama Surabaya tersebut. Sedangkan data sekunder, diperoleh melalui bahan hukum primer, bahan hukum sekunder dan bahan hukum tersier4, sebagai berikut :

Bahan hukum primer (primary resource atau authoritative records) berupa peraturan perundang-undangan yang berkaitan dengan waris dan mediasi antara lain : Reglemen Indonesia yang diperbaharui (HIR); Undang-Undang

3 Hutchinson, dalam Granita Ramadhani, Metodologi Penelitian Hukum, FHUI, Jakarta, 2000, Hlm.56-57.

${ }^{4}$ Soerjono Soekanto dan Sri Mamudji, Penelitian Hukum Normatif, Suatu Tinjauan Singkat, Rajawali Perselisihan dan pertengkaran, Jakarta, 2010, Hlm.15. dalam Oloan Sitorus dan Darwinsyah Minin, ibid. Hlm.36. Lihat pula NicoNgani, op.cit. Hlm.78
Nomor 48 Tahun 2009 tentang Kekuasaan Kehakiman; Undang-Undang Nomor 7 Tahun 1989 tentang Peradilan Agama sebagaimana telah diubah dan ditambah dengan Undang-Undang Nomor 3 Tahun 2006 dan Perubahan kedua dengan Undang-Undang Nomor 50 Tahun 2009; Undang-Undang Nomor 30 tahun 1999 Tentang Arbritase dan Alternatif Penyelasaian Sengketa; Inpres No. 1 Tahun 1991 tentang Kompilasi Hukum Islam; Peraturan Mahkamah Agung RI Nomor 1 Tahun 2008 tentang Prosedur Mediasi di Pengadilan; Peraturan Mahkamah Agung RI Nomor 1 Tahun 2016 tentang Prosedur Mediasi di Pengadilan.

Untuk memperoleh data lapangan dipergunakan metode metode dokumentasi dan metode Interview, selanjutnya bahan hukum tersebut diolah dengan pendekatan kualitatif, dengan cara antara lain dilakukan sistimatisasi dan klasifikasi terhadap bahan-bahan hukum untuk selanjutnya dianalisis, dikomparasi dan dilakukan konstruksi hukum terkait dengan optimalisasi mediasi perkara waris di Pengadilan Agama. Lokasi penelitian dalam penelitian ini dilakukan di wilayah Pengadilan Tinggi Agama Surabaya, yang mencakup 37 Pengadilan Agama yang bernaung di wilayah Pengadilan Tinggi Agama Surabaya. Oleh karena penelitian ini adalah perpaduan penelitian hukum 
normatif dan penelitian hukum empiris, yang datanya diperoleh melalui data primer dengan cara dokumentasi dan wawancara, dan diperoleh melalui bahan hukum primer, sekunder maupun tersier, maka dalam menganalisis bahan hukum, dipergunakan analisis kualitatif baik secara dekriptif maupun perspektif.

\section{B. HASIL DAN PEMBAHASAN}

\section{Analisis Kompetensi Skill Mediator} dalam Menyelesaikan Perkara Waris Di Wilayah Pengadilan

\section{Tinggi Agama Surabaya}

Berdasarkan hasil temuan penelitian yang dilakukan diketahui bahwa kompetensi skill mediator merupakan salah satu faktor yang secara langsung berpengaruh dalam penyelesaian mediasi perkara waris. Mediator bersertifikat adalah seoarng yang secara profesional telah mendapatkan sertifikat mediator yang merupakan dokumen yang diterbitkan oleh Mahkamah Agung atau lembaga yang telah memperoleh akreditasi dari Mahkamah Agung5 yang menyatakan bahwa seseorang telah mengikuti dan lulus pelatihan sertifikasi Mediasi. Kualifikasi mengikuti dan lulus pelatihan sertifikasi mediator menunjukkan bahwa mediator bersertifikat dituntut untuk profesional dalam menjalankan tugas dan fungsinya.

\footnotetext{
5 Perma Nomor 1 Tahun 2016 Tentang Prosedur Mediasi, Pasal 1 Ayat (3)

Temuan penelitian dari dokumentasi Badilag, hasil wawancara, kajian pustaka dan kajian empiris menunjukkan bahwa khusus perkara waris pada periode tahun 2014 dan tahun 2015 yang ditangani oleh mediator bersertifikat di wilayah Pengadilan Tinggi Agama Surabaya, masih menunjukkan bahwa masih banyak yang belum berhasil mencapai kesepakatan, serta dari wawancara diketahui bahwa sebagian besar proses mediasi perkara waris banyak yang Tidak Berhasil diketahui berasal dari skill kompetensi mediator yang secara umum belum sepenuhnya memahami ilmu faraid, (Sda-01/Ic/1709/2016) dan (Sby01/Ia/1409/2016).

Kegagalan mediasi dilihat dari sudut mediator dapat juga diidentifikasi dari keterbatasan waktu yang dimiliki para mediator, lemahnya keterampilan/skill mediator, kurang motivasi dan gigih menuntaskan perkara, dan mediator bersertifikat yang memahami ilmu Faraid masih sedikit ${ }^{6}$. Temuan ini menunjukkan bahwa terdapat beberapa parameter dari keberadaan kompetensi skill mediator yang sebaiknya dimiliki oleh mediator dalam menyelesaikan sengketa perkara waris di wilayah Pengadilan Tinggi Agama Surabaya.

\footnotetext{
${ }^{6}$ Hasil wawancara Surabaya, 17 September 2016
} 
Lemahnya skill/keterampilan yang dirasakan oleh mediator terletak pada bidang ilmu bantu seperti penguasaan ilmu faraid, managemen konflik, dan kurangnya kalimat-kalimat yang mengggugah dan berpengaruh serta mampu memberi daya dorong bagi para pihak untuk jernih melihat persoalan. Salah satu hakim di wilayah Pengadilan Tinggi Agama Surabaya berpendapat bahwa cara ini efektif untuk membangun kadar komunikasi kepada para pihak yang bersengketa, termasuk pilihan kata yang digunakan. Tentu cara ini tidak salah, namun dari sisi efektivitas dipandang kurang fokus pada upaya menggali faktorfaktor penyebab konflik utama (root causes), bukan pada pemicu konflik (triggers).

Para pihak yang bersengketa menginginkan agar kepentingannya tercapai, hak-haknya dipenuhi, kekuasannya diperlihatkan dan dipertahankan, sehingga untuk mewujudkan titik temu yang bisa diterima oleh para pihak yang bersengketa tersebut, relevan dengan teori yang diajarkan pada saat pelatihan sertifikasi mediator adalah dengan menentukan standart titik temu dalam sebuah proses mediasi perkara waris atau lebih dikenal dengan BATNA (Best Alternative To a Negotiated Agreement) atau Alternatif Terbaik Bagi Kesepakatan. Memberikan pemahaman yang baik soal standarisasi titik temu kepada para pihak untuk mencapai kesepakatan terkhusus masalah perkara waris, maka solusi yang efektif adalah menyadarkan para pihak sebagai umat muslim untuk bersandar kepada Al Qur'an dan Al Hadist, yang mengatur masalah waris secara hakiki dan bisa diterima oleh umat Islam. Di dalam agama Islam ilmu yang mengatur pembagian, siapa yang memperoleh hak waris dan persentase kuantitas yang diterima oleh yang berhak sudah di atur secara komprehensif dalam sebuah ilmu yaitu ilmu Faraid.

Berdasarkan uraian lemahnya kompetensi skill yang dimiliki oleh mediator bersertifikat, secara langsung berdampak terhadap minimnya proses mediasi di wilayah Pengadilan Tinggi Agama Surabaya mencapai kesepakatan, serta menunjukkan implikasi negatif yang begitu jelas, yaitu sebagai berikut:

1. Proses mediasi perkara waris yang ditangani banyak yang tidak mencapai kesepakatan

2. Memberi kesan nyata bahwa mediasi hanya sebatas formalitas dan menunggu untuk dilanjutkan ke ranah litigasi.

3. Semakin menambah beban penumpukan perkara di Pengadilan Agama-Pengadilan Agama di wilayah Pengadilan Tinggi Agama Surabaya.

4. Secara tidak langsung dapat berdampak terhadap tidak terwujudnya kepastian 
hukum bagi pencari keadilan, terkhusus para pihak yang bersengketa.

5. Tidak dapat mewujudkan upaya reformasi birokrasi Mahkamah Agung Republik Indonesia yang berorientasi pada visi terwujudnya badan peradilan Indonesia yang agung.

Alternatif dari serangkaian solusi yang paling tepat menurut analisis penulis adalah secara berkesinambungan dan terintegrasi berbagai pihak terkait yaitu dengan berorientasi kepada peningkatan kompetensi skill mediator, dengan jalan mengoptimalkan penerapan dari Perma Nomor 1 tahun 2016 Tentang Prosedur Mediasi, Pasal 12, Ayat (1), huruf a dengan jalan selalu fokus serta menindaklanjuti hasil pengkajian dan penelitian terhadap kondisi mediasi terkhusus perkara waris yang mana sebagian besar proses mediasi perkara waris diketahui berstatus Mediasi Tidak Berhasil. Proses tindaklanjut yang dimaksud adalah dengan meningkatkan kualitas dari kapasitas dan kompetensi skill mediator bersertifikat yang bertugas di wilayah Pengadilan Tinggi Agama Surabaya pada khususnya dan Pengadilan Agama-Agama di seluruh Indonesia pada khususnya.

Langkah selanjutnya adalah relevan dengan Perma Nomor 1 tahun 2016 Pasal 12, Ayat (1), huruf c Tentang Prosedur Mediasi, di mana solusi menurut penulis yang diasakan efektif adalah pelaksanaan evaluasi terhadap lembaga yang terakreditasi adalah meminta pihak terkait (lembaga yang terakreditasi dalam melakukan pelatihan mediator) untuk menambah satu kurikulum materi penguasaan ilmu faraid pada saat proses pelatihan sertifikasi mediator, sehingga kompetensi skill mediator pada saat lulus pelatihan benar-benar sudah relevan dan dapat memenuhi kebutuhan dalam proses memediasi perkara waris di Pengadilan Agama di wilayahnya bertugas.

Bilamana perlu serta guna menegakkan wibawa dan visi terwujudnya Badan Peradilan Indonesia Yang Agung maka dapat dilakukan rekonstruksi terhadap Perma Nomor 1 tahun 2016 Tentang Prosedur Mediasi terkhusus syarat dan evaluasi lembaga terakreditas agar memiliki dan sanggup untuk melakukan pelatihan secara intensif terhadap ilmu faraid dan ilmu-ilmu yang dirasakan perlu dalam memediasi misal ilmu ekonomi syariah, ilmu psikologis dan ilmu komunikasi lebih mendalam.

2. Analisis Implementasi Mediasi dalam Memberi Kemaslahatan Bagi Para Pihak Yang Bersengketa Perkara Waris di Wilayah Pengadilan Tinggi Agama Surabaya

Berdasarkan temuan penelitian penulis berkaitan dengan proses mediasi 
perkara waris dalam memberikan kemaslahatan di lingkungan wilayah Pengadilan Tinggi Agama Surabaya dapat dikemukakan kondisinya secara umum, dari beberapa Pengadilan Agama Pengadilan Agama adalah sebagai berikut: Pengadilan Agama Tulungagung (Tlg01/IIac/1009/2015), Pengadilan Agama eks karesidenan Surabaya, (Sby01/IIac/1409/2016), Pengadilan Agama Sidoarjo (Sda-01/IIac/1709/2016) diketahui pelaksanaan mediasi perkara waris yang dilakukan sudah sesuai dengan prosedur dan aturan baik Perma nomor 1 tahun 2008 maupun setelah disempurnakan dengan Perma Nomor 1 tahun 2016 Tentang Prosedur Mediasi, temuan fakta di lapangan menunjukkan bahwa meskipun prosedurnya sudah benar, realitanya masih banyak yang melanjutkan ke arah litigasi, sehingga tidak tercapai kesepakatan di antara para pihak, atau dikatakan proses mediasi gagal, dan kondisi inilah yang banyak dialami oleh Pengadilan AgamaPengadilan Agama di wilayah Pengadilan Tinggi Agama Surabaya.

Proses mediasi yang berjalan di PTA Wilayah Surabaya sepanjang periode tahun 2014 dan tahun 2015, bila merunut dari pengertian dan prosedur hukum saat itu yakni Perma nomor 1 tahun 2016, maka sebagaimana Pengadilan Agama di seluruh Indonesia, pelaksanaan mediasi di PTA
Wilayah Surabaya mengacu pada aturanaturan tersebut. ${ }^{7}$

Harapan agar implementasi mediasi memberi Kemaslahatan bagi Para Pihak yang bersengketa perkara waris, tidak terlepas dari upaya perwujudan kemaslahatan yang dalam disertasi ini teori mașlahat digunakan sebagai middle theory untuk mengetahui manfaat pengintegrasian mediasi dalam beracara menyelesaikan perkara waris di pengadilan Agama. Tentu saja tidak dapat mengabaikan penggunaan teori hukum Islam yang juga telah digunakan oleh kalangan pemikir sebelumnya. Al-maşhlahah seperti dikemukakan pada bab terdahulu, menduduki posisi yang sangat penting dalam menetapkan hukum, berkenaan dengan kasus harta bersama di Pengadilan Agama, oleh karena harta bersama adalah tidak terdapat dalam fikih klasik dan hal ini termasuk pembaharuan hukum Islam di Indonesia melalui Undang-Undang Nomor 1 Tahun 1974 tentang Perkawinan dan Kompilasi Hukum Islam.

Proses penyelesaian sengketa dengan dibantu oleh pihak ketiga dalam Islam dikenal dengan hakam berdasarkan firman Allah berikut.

"Dan jika kamu khawatirkan ada persengketaan antara keduanya,

\footnotetext{
${ }^{7}$ Prosedur Mediasi di Pengadilan Agama Kabupaten Malang (Online) (diakses di http://www.pa-malangkab.go.id/, tanggal 15 Oktober 2015)
} 
maka kirimlah seorang hakam dari keluarga laki-laki dan seorang hakam dari keluarga perempuan. Jika kedua orang hakam itu bermaksud mengadakan perbaikan, niscaya Allah memberi taufik kepada suami-istri itu."

Ayat di atas menganjurkan adanya pihak ketiga sebagai penengah atau mediator dalam penyelesaian sengketa. Keberadaan pihak ketiga sangat penting dalam menjembatani para pihak yang bersengketa. Keberadaan mediasi yang tidak terlepas dari upaya mendamaikan para pihak dengan mengutamakan musyawarah, juga memiliki landasan religi yang cukup tinggi dan kokoh, di mana dalam ketatanegaraan Islam, dikenal istilah "ahli syura". Hakekat pelaksanaan musyawarah itu sendiri menurut ulama dapat dikemukakan sebagai berikut: AsySyaikh Abdurrahman as-Sa'di rahimahullah mengatakan, "Jika Allah subhanahu wa ta'la mengatakan kepada Rasul-Nya-padahal beliau adalah orang yang paling sempurna akalnya, paling banyak ilmunya, dan paling bagus idenya-, 'Maka bermusyawarahlah dengan mereka dalam urusan itu', maka bagaimana dengan yang selain beliau?" (Taisir al-Karimirrahman, hlm. 154).

Analisis ini mempergunakan pendekatan teori kemaslahatan dengan teori dasar maqashid al-syar`iyah yang bermakna memelihara keturunan dan harta sebagaimana dalam prinsip dharûriyyah. Menyelesaikan sengketa hukum keluarga berupa kasus harta bersama, kasus harta warisan, kasus pemeliharaan anak bagi pihak suami istri yang cerai dengan cara kesepakatan perdamaian melalui proses mediasi, dengan demikian berarti menutup sebagian kemungkinan terjadinya kerenggangan hubungan kekeluargaan.

Berdasakan hasil penelitian tersebut maka dapat dikemukakan bahwa dari segi kemaslahatan yang diharapkan belum sepenuhnya optimal dirasakan oleh para pihak yang bersengketa perkara waris, hal ini merupakan implikasi dari serangkaian upaya oleh mediator khususnya hal musyawarah dalam menangani proses mediasi, yang mana seyogyanya dapat mengkaitkan konsep dan mencari titik temu pembagian waris diantara para pihak berkaitan dengan sengketa perkara waris diantara mereka.

\section{Analisis Efektivitas Mediasi}

Dihubungkan dengan Teori

Kepastian Hukum Dalam

Penyelesaian Sengketa Perkara Waris di Wilayah Pengadilan Tinggi Agama Surabaya

Hakim mediator ditunjuk oleh majelis hakim atau oleh para pihak yang meminta seorang hakim untuk 
memediasikan perkara mereka. Hakim harus bersedia menjadi mediator, bila ia diminta para pihak untuk menyelesaikan perkara mereka melalui jalur mediasi. 8

Berdasarkan teori efektifitas hukum yang dikemukakan oleh Soejono Soekanto, efektif tidaknya suatu hukum ditentukan oleh 5 (lima) faktor: 9

Faktor-faktor tersebut mempunyai arti yang netral, sehingga dampak positif atau negatifnya terletak pada isi faktor-faktor tersebut. Faktor Pertama, adalah faktor hukumnya sendiri, yaitu Undang-undang, dalam penelitian ini adalah Perma Nomor 1 Tahun 2016 Tentang Prosedur Mediasi di Pengadilan. Yang Kedua, adalah faktor penegak hukum yaitu para pejabat hukum di Pengadilan Agama wilayah Pengadilan Tinggi Agama Surabaya. Ketiga, faktor sarana atau fasilitas yang mendukung penegakan hukum, karena tanpa adanya sarana dan fasilitas tersebut, maka tidak mungkin penegakan hukum akan berjalan dengan lancar. Keempat, adalah masyarakat, yaitu lingkungan di mana hukum tersebut berlaku atau diterapkan. Kelima, faktor

\footnotetext{
${ }^{8}$ Syahrizal Abbas, Mediasi Dalam Hukum Syariah, Hukum Adat, dan Hukum Nasional, (Jakarta:Kencana, 2011), hlm. 318-319

${ }_{9}$ www.detikhukum.wordpress.com. Diakses pada 30 Agustus 2017.
}

kebudayaan yang pada dasarnya mencakup nilai-nilai yang mendasari hukum yang berlaku.

Berdasarkan temuan hasil penelitian penulis proses pelaksanaan mediasi perkara waris di Pengadilan Agama wilayah Pengadilan Tinggi Agama Surabaya tidak berpengaruh pada jumlah perkara yang masuk di pengadilan. Serta tidak dapat menekan terjadinya peningkatan penyelesaian sengketa perkara waris, secara otomatis harapan Mahkamah Agung untuk mengurangi penumpukan perkara pada pengadilan tingkat Banding belum bisa terealisasi.

Berdasarkan penjelasan Perma nomor 1 tahun 2016 salah satu poinnya adalah melaksanakan kaukus kepada para pihak, serta dapat menginventarisasi permasalahan dan mengagendakan pembahasan berdasarkan skala proritas, keberadaan dan kejelian mediator dalam memahami permasalahan dan melakukan pembahasan berdasarkan skala prioritas dapat dimaknai sebagai upaya mediator untuk memberikan penjelasan kepada para pihak mengenai prioritas yang baikdan benar sesuai sengketa perkara waris adalah kembali kepada ilmu waris yakni faraid, keterampilan dan pemahaman (soal ilmu faraid) mediator pada saat kaukus menjadi salah satu poin lebih bagi para pihak untuk 
secara kekeluargaan dan sukarela menerima apa yang menjadi haknya.

Jadi peran mediator adalah hanya bersifat membantu para pihak dengan cara tidak memutus dan memaksakan pandangan atau penilaian atas masalahmasalah selama proses mediasi berlangsung kepada para pihak. Dalam praktik, mediator sangat membutuhkan kemampuan personal yang memungkinkannya berhubungan secara menyenangkan dengan para pihak. Kemampuan pribadi yang terpenting adalah sifat tidak menghakimi, yaitu dalam kaitannya dengan cara berfikir masingmasing pihak.

Adapun hal-hal yang perlu dilakukan oleh seorang mediator dalam praktik, menurut penulis antara lain sebagai berikut: 1.Melakukan diagnosis konflik; 2.Mengidientifikasi masalah serta kepentingan-kepentingan kritis para pihak; 3.Menyusun agenda; 4.Memperlancar dan mengendalikan komunikasi; 5.Mengajar para pihak dalam proses dan keterampilan tawar- menawar; 6.Membantu para pihak mengumpulkan informasi penting, dan menciptakan pilihan-pilihan untuk memudahkan penyelesaian problem.

Dalam kaitannya dengan itu, tugas mediator adalah mengarahkan dan memfasilitasi lancarnya komunikasi dan membantu para pihak agar memperoleh pengertian tentang perselisihan secara keseluruhan sehingga memungkinkan setiap pihak membuat penilaian yang objektif.

Penyelesaian secara damai merupakan jalan yang terbaik bagi semua pihak, penggunaan jalur litigasi yang panjang dan berbelit-belit pada akhirnya hanya sebagai sarana untuk menunjukkan sikap egois semata. Para pihak yang tetap berkeras menginginkan agar penyelesaiannya diputuskan oleh pengadilan biasanya mengandung konflik non hukum di luar pokok sengketanya, misalnya diantara para pihak terlibat konflik emosional, dendam dan sentimen pribadi. Hal inilah yang sering mengemuka menjadi dinding penghalang terjadinya perdamaian diantara para pihak. ${ }^{10}$

Kepastian adalah tujuan hukum yang paling minimal yang harus dicapai melalui asumsi-asumsi Positivisme Hukum. Sebab hukum tanpa nilai kepastian akan kehilangan makna, karena tidak lagi dapat dijadikan pedoman perilaku bagi semua orang, artinya di mana tiada kepastian hukum, di situ tidak ada hukum (ubi jus incertum, ibi jus nullum).

Kepastian Hukum adalah tujuan utama dari hukum. ${ }^{11}$ Berangkat dari

10 D.Y Witanto, Hukum Acara Mediasi Dalam Perkara Perdata di Lingkungan Peradilan Umumdan Peradilan Agama Menurut PERMA No. 1 Tahun 2008 Tentang Prosedur Mediasi di Pengadilan. Bandung: Alfabeta, 2012. Hlm. 69

11 J.B. Daliyo, Pengantar ilmu Hukum, Gramedia Pustaka Utama, Jakarta, 2001, hlm.120. 
pernyataan tersebut, maka tugas kaedahkaedah hukum adalah untuk menjamin adanya kepastian hukum. ${ }^{12}$ Dengan adanya pemahaman kaedah-kaedah hukum tersebut, masyarakat sungguh-sungguh menyadari bahwa kehidupan bersama akan tertib apabila terwujud kepastian dalam hubungan antara sesama manusia.

Temuan penelitian ini selanjutnya dapat dikaji secara ilmiah bahwasanya dengan mediator yang memiliki kualitas, kapabiltas dan integritas yang baik sesuai dengan profesionalisme dan kompetensi mediator maka perwujudan kepastian hukum bagi para pihak yang bersengketa, pada akhirnya dapat terwujud akta perdamaian yang sesuai harapan tanpa melalui proses litigasi.

Penyelesaian damai berarti terjadi pemeliharaan harta serta memelihara keturunan. Setelah terungkap hubungan tersebut, maka terungkap pula manfaat penyelesaian perkara secara damai melalui proses mediasi.

Sehingga secara ilmiah dapat dikemukakan bahwa pelaksanaan mediasi perkara waris yang efektif dapat mendukung tecapainya kepastian hukum di masyarakat secara umum, terkhusus para pihak yang bersengketa perkara waris di wilayah Pengadilan Tinggi Agama Surabaya. Temuan in-deep interview dan

\footnotetext{
${ }^{12}$ Sudarsono, Pengantar Ilmu Hukum, Rineka Cipta, Jakarta, 1995, hlm. 49.
}

analisis diketahui bahwa efektivitas mediasi perkara waris di wilayah Pengadilan Tinggi Agama Surabaya belum berjalan dengan efektif, setidaknya hal ini dikarenakan masih banyak sengketa perkara waris yang ditangani Pengadilan Agama-Pengadilan Agama yang tidak mencapai perdamaian dan berlanjut ke ranah litigasi selanjutnya. Di lain sisi dapat dikemukakan pula bahwa implikasi mediasi perkara waris yang dapat mencapai akta perdamaian bagi para pihak, sehingga diharapkan secara aksiologis dapat memberikan kepastian hukum bagi para pihak yang bersengketa.

Berdasarkan pemaparan dan pembahasan analisis-analis di atas, maka urgen dilaksanakan sebuah upaya yang terintegrasi dari berbagai stake holder untuk mengupayakan efektivitas mediasi terkhusus perkara waris dapat berjalan dengan efektif dan mewujudkan kepastian hukum. Upaya tersebut adalah sebagai berikut:

a. Dalam upaya peningkatan kualitas diharapkan pihak MA melakukan rekonstruksi kurikulum terhadap lembaga pelatihan mediator yang ditunjuk, dengan jalan lembaga terkait untuk memberikan materi yang berkaitan dengan skill kompetensi tambahahan yakni materi ilmu faraid, pada saat proses pelatihan dan sertifikakasi mediator yang dilakukan 
oleh badan yang telah diakreditasi MA dalam melaksanakan pelatihan mediator.

b. Meningkatkan fungsi evaluasi dengan dibentuk tim pengawas implementasi proses mediasi di masing-masing Pengadilan Agama di bawah Hawasbid (Hakim Pengawas Bidang) yang secara berkesinambungan untuk dilaporkan kepada Ketua Asosiasi Mediator melalui Ketua Pengadilan.

c. Konsisten dalam melaksanakan proses mediasi yang selalu terukur dan sesuai dengan Perma Nomor 1 tahun 2016 Tentang Prosedur Mediasi.

\section{KESIMPULAN DAN SARAN}

Berdasarkan kajian analisis yang dilakukan dalam penelitian ini, maka dapat dikemukakan kesimpulan dari hasil penelitian adalah sebagai berikut:

1. Temuan penelitian ini, diketahui bahwa kompetensi skill yang dimiliki oleh mediator bersertifikat yang menangani perkara waris belum optimal, hal ini secara langsung berdampak terhadap minimnya keberhasilan proses mediasi di wilayah Pengadilan Tinggi Agama Surabaya mencapai kesepakatan. Berdasarkan temuan penelitian ini juga diketahui bahwa sebagian besar sengketa perkara waris yang masuk di Pengadilan Agama, terkhusus yang berhasil damai, di mediasi olaeh mediator hakim, yang secara kompetensi mempunyai pemahaman ilmu Faraid yang baik. Hal ini juga menunjukkan bahwa pentingnya penguasaan komptensi dalam hal ilmu faraid oleh para mediator yang bersertifikat.

2. Implementasi mediasi bagi para Pihak Yang bersengketa perkara waris di Wilayah Pengadilan Tinggi Agama Surabaya sudah berjalan sesuai dengan prosedur mediasi yang di atur dalam Perma Nomor 1 tahun 2016 Tentang Prosedur Mediasi, namun dari segi kemaslahatan yang diharapkan belum sepenuhnya optimal dirasakan oleh para pihak yang bersengketa perkara waris, hal ini merupakan implikasi dari serangkaian upaya oleh mediator khususnya hal musyawarah dalam menangani proses mediasi, yang mana seyogyanya dapat mengkaitkan konsep dan mencari titik temu pembagian waris diantara para pihak berkaitan dengan sengketa perkara waris diantara mereka. Bilamana upaya kemaslahatan untuk mencari titik temu pembagian waris sudah jelas dan dapat disampaikan dengan ilmiah, netral tidak memihak serta sesuai dengan kaidah untuk mengupayakan perdamaian dengan memberikan pemahaman yang baik soal standarisasi 
titik temu kepada para pihak yang akan dimediasi

3. Secara ilmiah dapat dikemukakan bahwa pelaksanaan mediasi perkara waris yang efektif dapat mendukung tercapainya kepastian hukum di masyarakat secara umum, terkhusus para pihak yang bersengketa perkara waris di wilayah Pengadilan Tinggi Agama Surabaya. Temuan in-deep interview dan analisis diketahui bahwa efektivitas mediasi perkara waris di wilayah Pengadilan Tinggi Agama Surabaya belum berjalan dengan efektif, setidaknya hal ini dikarenakan masih banyak sengketa perkara waris yang ditangani Pengadilan AgamaPengadilan Agama yang tidak mencapai perdamaian dan berlanjut ke ranah litigasi selanjutnya. sepanjang periode tahun 2014 hingga 2015, bahkan hingga saat ini, sehingga kepastian hukum dalam penyelesaian sengketa perkara waris melalui mediasi di Pengadilan Agama wilayah Pengadilan Tinggi Agama Surabaya belum efektif.

Adapun saran yang dapat diberikan adalah:

1. Perlu ditambahkan materi ilmu faraid dalam proses sertifikasi mediator, hal ini merupakan solusi yang efektif terhadap seringnya kegagalan proses mediasi perkara waris di Pengadilan
Agama khususnya wilayah Pengadilan Tinggi Agama Surabaya. Sehingga disarankan pihak yang berkompeten dalam hal ini Mahkamah Agung untuk menerbitkan Perma khusus untuk sertifikasi bagi mediator perkara waris.

2. Implementasi mediasi perkara waris sudah sesuai dengan prosedur dalam Perma nomor 1 tahun 2016, namun masih ditemukan implementasi tersebut cenderung formalitas semata, sehingga disarankan dibentuk tim pengawas implementasi proses mediasi di masing-masing Pengadilan Agama di bawah Hawasbid (Hakim Pengawas Bidang) yang secara berkesinambungan untuk dilaporkan kepada Ketua Asosiasi Mediator melalui Ketua Pengadilan.

3. Mengharapkan diterbitkannya perundang-undangan dalam hal kemampuan kompetensi para mediator untuk memiliki skill yang profesional dan kompeten dalam hal komunikasi, ilmu waris dan juga mediator skills, Following skills dan Reflecting skills sehingga mediator dapat mewujudkan pencapian kesepakatan melalui akta perdamaian seperti tujuan utama mediasi sehingga terwujud kepastian hukum dalam proses mediasi sengketa perkara waris.

\section{DAFTAR PUSTAKA}


D.Y Witanto, Hukum Acara Mediasi Dalam Perkara Perdata di Lingkungan Peradilan Umum dan Peradilan Agama Menurut PERMA No. 1 Tahun 2008 Tentang Prosedur Mediasi di Pengadilan. Bandung: Alfabeta, 2012.

Dokumen Reviu Rencana Strategis (Renstra) Mahkamah Agung Tahun 2015-2019, Penerbit Mahkamah Agung RI, Jakarta, April 2017

Hutchinson, dalamGranitaRamadhani, Metodologi Penelitian Hukum, FHUI, Jakarta, 2000.

J.B. Daliyo, Pengantar ilmu Hukum, Gramedia Pustaka Utama, Jakarta, 2001.

Perma Nomor 1 tahun 2016, tentang Prosedur Mediasi

Prosedur Mediasi di Pengadilan Agama Kabupaten Malang (Online) (diakses di http://www.pa-malangkab.go.id/, tanggal 15 Oktober 2015)

Soerjono Soekanto dan Sri Mamudji, Penelitian Hukum Normatif, Suatu Tinjauan Singkat, Rajawali Perselisihan dan pertengkaran, Jakarta, 2010, Hlm.15. dalam Oloan Sitorus dan Darwinsyah Minin.

Sudarsono, Pengantar Ilmu Hukum, Rineka Cipta, Jakarta, 1995.

Syahrizal Abbas, Mediasi Dalam Hukum Syariah, Hukum Adat, dan Hukum
Nasional, (Jakarta:Kencana, 2011), hlm. 318-319

www.detikhukum.wordpress.com. Diakses pada 30 Agustus 2017. 